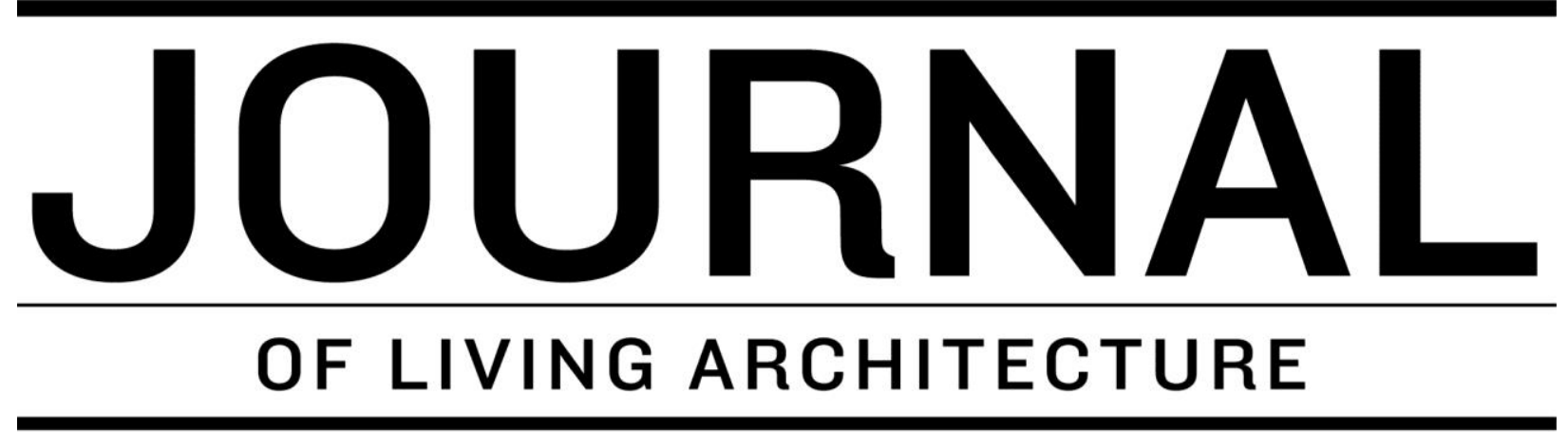

A GREEN ROOFS FOR HEALTHY CITIES PUBLICATION

Volume 2 Number 2 Pages 9-26

December 2015

\title{
Observation of biodiversity on minimally managed green roofs in a tropical city
}

Yun Hye HWANG

Department of Architecture, School of Design and Environment, National University of Singapore, 4 Architecture Drive Singapore 11756 yhwang@nus.edu.sg Phone: (65) 65163512 Fax: (65) 67791936

\section{Zi En Jonathan YUE}

Department of Architecture, School of Design and Environment, National University of Singapore, 4 Architecture Drive Singapore 11756

\begin{abstract}
While much of the land in Singapore has been urbanized, green roofs have the potential to be part of an urban ecosystem where limited human interference can promote natural processes. This study observes the establishment of flora and fauna communities on two newly installed green roofs using a mix of seeding, transplantation and spontaneous colonization installation methods and operating under minimal management over a period of 16 months. Recorded here are plant compositions and spatial distributions of flora growth of 64 species over this period. The minimally managed green roofs in this study possess increased plant species richness, highlighting a way to enhance urban diversity in a tropical city.
\end{abstract}

Key words: Green roof, Urban Biodiversity, Changes in flora and fauna, Minimal maintenance, Tropical city

Please Cite as: Hwang, Y.H., Z.E.J. Yue, 2015. Observation of biodiversity on minimally managed green roofs in a tropical city. Journal of Living Architecture. 2(2):9-26.

Available at ...ADD WEB URL

This peer-reviewed Article is provided free and open-access. 


\section{INTRODUCTION}

Urbanization causes intense and fundamental changes in biodiversity and ecosystem functions (Alberti, 2005; Collins et al., 2000), with human development degrading and fragmenting natural habitats (Forman, 1995; Soule et al., 1988), to the point where the environment of dense urban cores such as cities are mostly unable to sustain wildlife (McKinney, 2002). All is not lost however, as many scholars have stressed the role of the built environment as a vital component of the overall ecology of cities ( McDonnell \& Pickett, 1993; Pickett, Cadenasso, \& McGrath, 2013; Spirn, 1984).

Singapore is the most highly urbanized city state in South East Asia (United Nations, 2014). Continuous developments and deforestation have caused habitat destruction, resulting in widespread extinction and endangerment of biodiversity (Brook, Sodhi, \& Ng, 2003; Corlett, 1992; Laurance, 1999). Of the 2,053 recorded vascular plant species considered native or indigenous to Singapore, $89.14 \%$ are considered globally or nationally extinct, or threatened by extinction (Davison, Ng, Ho, \& Nature, 2008). Today, about half the green spaces in the city are being managed (Yee, Corlett, Liew, \& Tan, 2011); these landscapes typically consist of homogeneous plant communities low in biodiversity (Chong et al., 2014). Yet if the ecological functions of natural vegetation can be performed by these manmade landscapes, they can potentially contribute to urban wildlife in Singapore (T. W. H. Tan, 2010), where more than 40,000 wild species still coexist with a human population of five million $(\mathrm{Ng}$, Corlett, \& Tan, 2011).

In a high-density urban context where much green area on ground-level is lost, green roofs are increasingly regarded as an alternative space; with little competition for their use, they are readily set up to support a regional ecosystem, thus maximizing urban habitat value (Oberndorfer et al., 2007). Green roofs have the potential to achieve greater species diversity of faunal communities (Brenneisen, 2006; Coffman \& Waite, 2011; Pearce \& Walters, 2012); while not an exact replacement for ground level ecology, they are still comparable to the natural ecosystem (Ksiazek, Fant, \& Skogen, 2012; Schrader \& Böning, 2006). In addition, they aid endangered species conservation (Brenneisen, 2005; Gedge \& Kadas, 2005); (Kadas, 2010) and facilitate the movement of organisms by connecting to other urban landscapes (Braaker, Ghazoul, Obrist, \& Moretti, 2014). Furthermore, design strategies to enhance the ecological value of green roofs have been discussed in experimental research investigating soil types and depth (Brenneisen, 2004; Dunnett, Nagase, \& Hallam, 2008), and vegetation structure diversity (Baumann \& Kasten, 2010; Gedge \& Kadas, 2005; Köhler, 2006; Madre, Vergnes, Machon, \& Clergeau, 2013). In short, viewed from the highly-urban context of Singapore where there is an abundance of roof-space, green roofs can be promising components of the enhancement of biodiversity in the city-state.

In Singapore, more than $60 \mathrm{Ha}$ of rooftop greenery have been installed to date (National Parks Board, 2013), with a projected 50Ha more by 2030 (Inter-Ministerial Committee on Sustainable Development, 2009). These projects are mostly supported by government initiatives such as the Skyrise Greenery Incentive Scheme (SGIS), which funds up to $50 \%$ of installation costs of rooftop greenery (National Parks Board, 2009). Standards and guidebooks have been published by the research department of Singapore's national agency for green development to facilitate various aspects of rooftop greenery, such as loading and safety requirements, plants, and substrates (Centre for Urban Greenery \& Ecology (Singapore) \& National Parks Board (Singapore), 2010a, 2010b, 2010c, 2010d, 2012a, 2012b, 2012c, 2013a, 2013b, 2014a, 2014b; P. Y. Tan \& Sia, 2008). While rooftop greenery comprises both roof gardens and green roofs, the 
idea of an ecological network can be explored through the implementation of green roofs which, unlike roof gardens, can be easily installed on most existing roofs without structural improvements. Although the lightweight profile of the extensive green roof limits the plant palette due to comparatively lower water retention and shallower substrate (Snodgrass \& McIntyre, 2010; P. Y. Tan \& Sia, 2008), several studies show green roofs provide various environmental benefits in Singapore, including improving thermal performance in the tropical climate (Wong, Tan, \& Chen, 2007), moderating and delaying the peak runoff of storm water (Qin, Wu, Chiew, \& Li, 2012), and even reducing life cycle costs as compared to both exposed flat roofs and rooftop gardens (Wong, Tan, Wong, Ong, \& Sia, 2003). Despite growing interest and research, however, there is little awareness of the ecological aspects of these spaces in Singapore.

Studies show plants that flourish without intensive maintenance can achieve biodiversity easily (Grime, 1998), especially in the tropical conditions of Singapore (Hwang, 2010). Lawns left alone in Singapore have resulted in a much higher floral richness, with ruderal species like Mimosa pudica, Vernonia cinerea, and Sporobolus indicus providing ecological services to fauna through sufficient plant volume to support mini-ecosystems of insects (Hwang, 2015). Given the quick growth and low cost of using and maintaining such species, this may be a valuable way to establish biodiversity on green roofs.

In summary, this research investigates the ecological services of green roofs in a tropical urban context by examining the establishment of spontaneous succession of ruderal vegetation on green roofs in a tropical urban context through a combination of broad cast seed installation, transplantation, and spontaneous colonization. These techniques are further combined with lowinput maintenance in order to examine a less conventional approach to green roof plant establishment. We profile a list of the flora and fauna that develop on the green roofs, documented species richness and percentage coverage of each taxa of flora, and analyze the spatial distribution plans of the green roofs over time. The first section of the paper summarizes the methodology involved, including installation of the research sites and observation methods employed. Findings are reported in the second section and the final section initiates the further discussion for green roofs to be considered as a crucial element of the tropical urban ecosystem.

\section{METHODOLOGIES}

\section{Studied sites}

The sites studied were in Singapore, a city state located 1 degree north of the equator. Its climate is typically hot and humid, with little month-to-month variation for temperature or rainfall. It has a mean diurnal temperature range of $24.1-31.0^{\circ} \mathrm{C}$ and a mean annual rainfall of 2338.5mm with 178 annual mean rain days (National Environment Agency, 2013).

During December 2012, two experimental green roofs were constructed on separate concrete roofs on the National University of Singapore campus, which was built in the late 1970s. An extensive green roof of area $662 \mathrm{~m}^{2}$ was constructed on the School of Design and Environment (Roof A), and another of area $79 \mathrm{~m}^{2}$ on the Faculty of Arts and Social Sciences (Roof B). The roofs were located at equal AMSL heights, each having an allowable imposed load of $4 \mathrm{kN} / \mathrm{m}^{2}$. Since the research was intended as a means to observe the degree of biodiversity that could be supported by a typical green roof, the most common roof assembly in the local market was used in both: $25 \mathrm{~mm}$ drainage cells, a filter sheet and a growing course of $50 \mathrm{~mm}$ depth of soil medium, comprising loamy soil, compost, and pumice in a 2:1:1 ratio. The 
construction costs were in the lower range of average costs for green roofs in Singapore, (\$104.14/m² (SGD).

A low-input approach was applied to the test roofs. No fertilizers were used; removal was only done on aggressive plants which could have dominated the entire area. For example, Imperata cylindrica, Ischaemum muticum, Ipomea obsura and Mikania micrantha were removed when observed to be growing densely. Trimming was done for tall overgrown trees to prevent them from falling over. Acacia species, which have weak stems that frequently collapse, were removed for safety considerations when noted to be growing. Trees such as Leucana leucocephala, Sesbania sesban and Mimosa pigra were trimmed to a $3 \mathrm{~m}$ height once every 6 months. Crotalaria was trimmed from $1.8 \mathrm{~m}$ to $1.0 \mathrm{~m}$ on Roof B after 12 months to see if this would help the growth of species growing under it. Roofs were irrigated during plant establishment (the first 3 months); if there was no rain for more than 5 days, they were irrigated once a day until it rained again.

Three methods of plant installation were used over the first 5 months - seeding, transplanting, and spontaneous growth. Transplanting ensured some vegetation was present from the start of the research; these areas could be compared to areas utilizing broad cast seeding or left as bare substrate to determine their suitability in establishing biodiversity on a green roof. A quarter of Roof A and one half of Roof B were sown with seeds of 35 species of shrubs, herbs, grasses and sedges collected from ground-level ruderal populations with environmentally stressful conditions similar to rooftops - a dumping ground in Lorong Halus, a wild field on Old Holland Road, and the edges of the former KTM railway. A second quarter of Roof A was also seeded with 15 species of drought tolerant plants. Another quarter of Roof A was transplanted with mature specimens of 11 ruderal species collected from the aforementioned sites. The most commonly planted ground cover in Singapore, Axonopus compressus, was planted in a portion of both roofs to observe how it would fare on a green roof, especially compared to other vegetation. Finally, the rest of the areas were left bare to study possibilities of self-generating vegetation. The settings of the two studied sites are summarized in Table 1.

\section{Observation methods}

The vegetative observations ran from December 2012 to April 2014 for a total of 16 months; during this time, plants on each site were identified and recorded every 2-3 months. Plants were recorded and analyzed in two ways.

First, to gauge the overall species richness of plants, the total number of individual species was counted and listed by vegetation structure with the indication of planting types. The flora species observed were broken down into 8 types of vegetation structure. These vegetation structure categories were meant to classify the flora, not by botanical characteristics but by broad visual and growth characteristics to assist in the understanding of their role in ecological niches (Lundholm, 2015; Murdoch, Evans, \& Peterson, 1972). Divided by vegetative structure, the main categories were 'trees,' 'shrubs and herbaceous plants,' 'grasses and sedges,' and 'creepers,' with 'shrubs and herbaceous plants' and 'grasses and sedges' further subdivided by height classes, based on their heights when fully grown; the shortest in both categories (below $0.2 \mathrm{~m}$ ) was classified as 'groundcover.'

Second, the coverage of plant species obtained from top-down photos of the site was mapped to read the growth pattern of plants. With a remote camera mounted on a six-meter extendable aluminum pole, top-down photos of the site were taken from a bird's eye view. Over 200 photos of Roof A and 50 photos of Roof B were stitched together for each mapping. Plants 
were identified using a combination of the aerial photos and on-the-ground observation, down to the species level where possible, or to a grouping of visually similar species within the same family. Identified plants were graphically represented using different colors on a scaled plan of dots that corresponded with ten-centimeter circles on the actual site, within which only the species with majority coverage were denoted. Percentage coverage was then calculated by counting the total number of dots for each species or species group and tabulating the result in a graph format.

Fauna were observed once every 2-3 months during the same period, 6 times altogether. The fauna found on site were recorded with macro and telephoto lenses and identified. As the focus of the research was on flora growth and diversity, the process did not include a detailed documentation of all fauna present each time. Instead, new fauna species spotted during each documentation period were added to an overall list of species. The cumulative number of fauna species was counted for each site; observed characteristics of listed fauna were noted as well.

\section{Limitation of observation methods}

This study recorded plant coverage based on aerial photos. Although the method is useful for understanding the growth patterns and spread of plant species, it has limitations. Since only the top layer of vegetation was recorded, the different layers of vegetation cannot be considered in the coverage table. On-site observations and photographs were used to supplement these, and are noted in the results below. In later months, with taller vegetation, $1.5 \mathrm{~m}$ and taller, the smaller shrub and groundcover layers were not properly represented in the mapping. Tall shrub growth was noted to be very dense on both roofs, so the lower layers of vegetation, if any, would be thin. Creepers cover the plants they grow on, similarly affecting the study's calculations of coverage, as only the plants with majority coverage within the $10 \mathrm{~cm}$-diameter circles were noted. As mentioned earlier, though, creepers were removed if their growth was too aggressive, thereby controlling their impact on plant coverage. This research did not anticipate the growth of large 3$5 \mathrm{~m}$ tall trees given the $5 \mathrm{~cm}$ substrate that was used; while their growth was an interesting addition, it resulted in significant discrepancies in the recorded plant coverage. As such, the total tree cover is noted in the coverage table and can be taken as an additional margin of error with regards to the other plant coverage. 
Table 1. Summary of roof settings

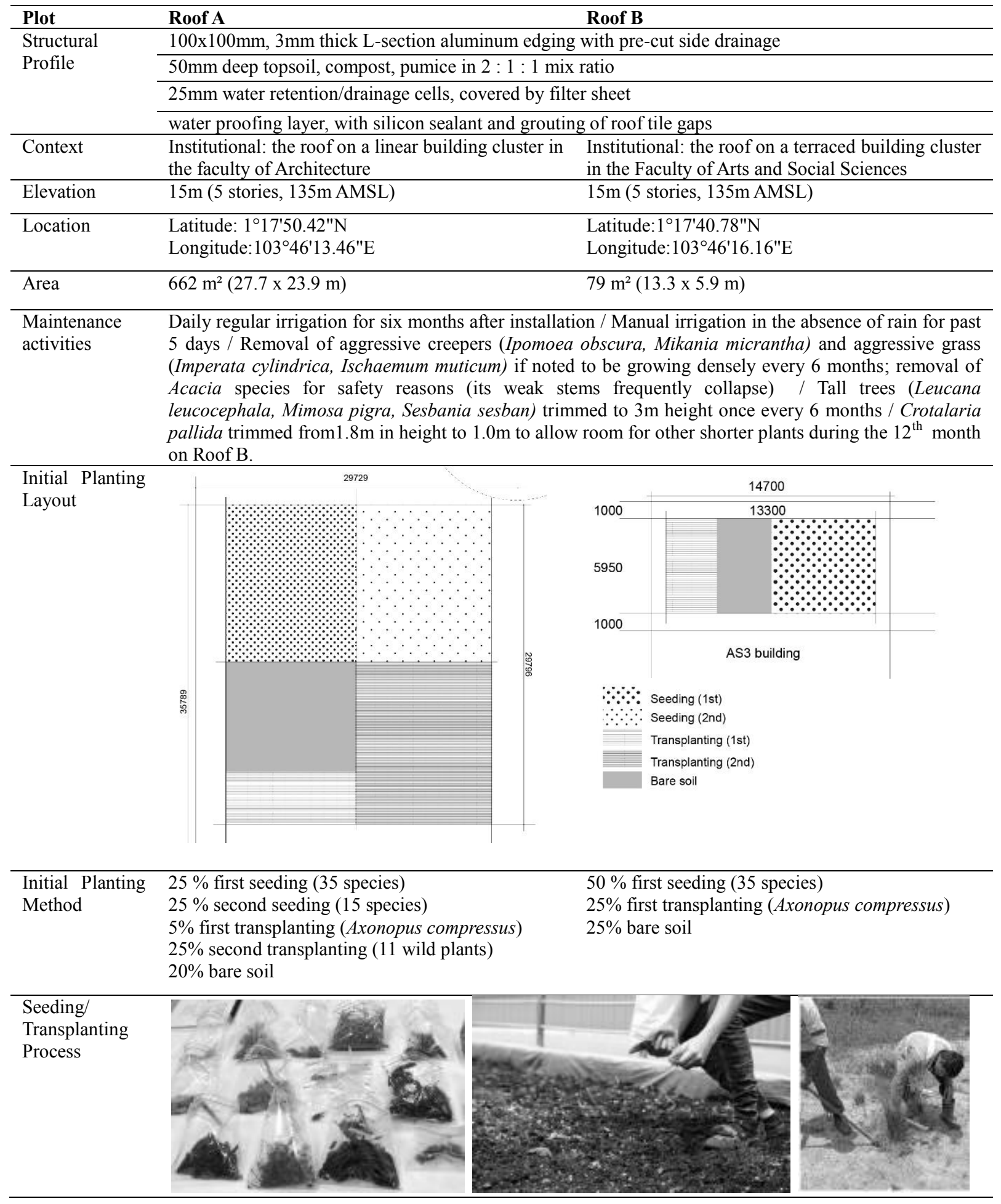




\section{RESULTS}

\section{Flora diversity}

The total number of species on each roof continued to increase, peaking at 64 and 23 species in the $16^{\text {th }}$ month for Roof A and B respectively. On Roof A, the 64 species of plants included 3 species of trees, 27 species of shrubs and herbaceous plants, 24 species of grasses and sedges, 6 creepers, and 4 groundcovers. Meanwhile, Roof B's 23 species consisted of 1 tree species, 11 species of shrubs and herbaceous plants, 7 grasses and sedges, 2 creepers and 2 groundcovers. Thirty-four of 64 species on Roof A and 19 of 23 species on Roof B in the $16^{\text {th }}$ month were generated spontaneously, from wind dispersal, insects or birds. Table 2 shows the increased number of total species and species richness sorted by vegetation types over time.

Table 2. Summary of plant species present on Roof A and Roof B (in grey) sorted by vegetation structure over time. Numbers in parentheses indicate spontaneous species.

\begin{tabular}{|c|c|c|c|c|c|}
\hline Category & $\begin{array}{r}\text { May 2013 } \\
\left(5^{\text {th }} \text { Month }\right) \\
\end{array}$ & $\begin{array}{r}\text { July 2013 } \\
\left(7^{\text {th }} \text { Month }\right) \\
\end{array}$ & $\begin{array}{r}\begin{array}{r}\text { October } 2013 \\
\left(10^{\text {th }} \text { Month }\right)\end{array} \\
\end{array}$ & $\begin{array}{r}\text { December } 2013 \\
\left(12^{\text {th }} \text { Month }\right) \\
\end{array}$ & $\begin{array}{r}\text { April 2014 } \\
\left(16^{\text {th }} \text { Month }\right)\end{array}$ \\
\hline \multirow{2}{*}{ Trees } & $1(0)$ & $3(1)$ & $3(1)$ & $3(1)$ & $3(1)$ \\
\hline & $0(0)$ & $0(0)$ & $1(1)$ & $1(1)$ & $1(1)$ \\
\hline \multirow{2}{*}{ Shrubs and Herbaceous plants } & $14(5)$ & $20(5)$ & $23(8)$ & $23(8)$ & $27(13)$ \\
\hline & $5(2)$ & $5(2)$ & $6(3)$ & $6(3)$ & $11(8)$ \\
\hline \multirow{2}{*}{ Grasses and Sedges } & $11(3)$ & $17(9)$ & $24(13)$ & $24(13)$ & $24(13)$ \\
\hline & $1(1)$ & $2(2)$ & $4(4)$ & $4(4)$ & $7(7)$ \\
\hline \multirow{2}{*}{ Creepers } & $2(1)$ & $4(2)$ & $5(3)$ & $5(4)$ & $6(5)$ \\
\hline & $1(1)$ & $1(1)$ & $1(1)$ & $1(1)$ & $2(2)$ \\
\hline \multirow{2}{*}{ Groundcovers } & $3(0)$ & $5(2)$ & $5(2)$ & $4(2)$ & $4(2)$ \\
\hline & $1(0)$ & $1(0)$ & $2(1)$ & $2(1)$ & $2(1)$ \\
\hline \multirow{2}{*}{ Total species richness } & $31(9)$ & $49(19)$ & $60(27)$ & $59(28)$ & $64(34)$ \\
\hline & $8(4)$ & $9(5)$ & $14(10)$ & $14(10)$ & $23(19)$ \\
\hline \multirow{2}{*}{ Tree coverage (\% of site) } & 0.3 & 1.9 & 4.5 & 9.6 & 10.2 \\
\hline & $\mathbf{0}$ & $\mathbf{0}$ & 0.1 & 0.9 & 0.3 \\
\hline \multirow{2}{*}{ Plant coverage ( $\%$ of site) } & $29.3(0.4)$ & $49.0(5.5)$ & $77.6(16.8)$ & $95.9(28.9)$ & $93.7(49.1)$ \\
\hline & $79.8(0.4)$ & $93.1(1.4)$ & $98.6(0.7)$ & $100.0(1.8)$ & $96.4(26.4)$ \\
\hline
\end{tabular}


Table 3. List of flora species on Roof A and Roof B by vegetation structure with the indication of planting types (* seeded; + transplanted; $\wedge$ spontaneous vegetation)

\begin{tabular}{|c|c|c|}
\hline \multirow{2}{*}{$\begin{array}{l}\text { Vegetation } \\
\text { structure }\end{array}$} & \multicolumn{2}{|l|}{ Plant species } \\
\hline & Roof A & Roof B \\
\hline Trees $(>3 \mathrm{~m})$ & $\begin{array}{l}\text { Leucaena leucocephala } * \text {, Sesbania sesban } * \text {, } \\
\text { Mimosa pigra }\end{array}$ & Acacia auriculiformis $^{\wedge}$ \\
\hline $\begin{array}{l}\text { Tall shrubs and } \\
\text { herbaceous plants } \\
(1.2-3.0 \mathrm{~m})\end{array}$ & $\begin{array}{l}\text { Crotalaria pallida }{ }^{*}, \text { Crotalaria retusa } * \text {, } \\
\text { Melastoma malabathricum }+, \text { Neptunia plena }{ }^{\wedge} \text {, } \\
\text { Ocimum basilicum }+, \text { Stachytarpheta indica }{ }^{+}\end{array}$ & $\begin{array}{l}\text { Crotalaria pallida } * \text {, Neptunia plena }{ }^{\wedge} \text {, } \\
\text { Ocimum basilicum }+ \text {, Stachytarpheta indica } \\
\wedge, \text { Asclepias curassavica } \wedge \text {, Chromolaena } \\
\text { odorata }^{\wedge}\end{array}$ \\
\hline $\begin{array}{l}\text { Medium shrubs and } \\
\text { herbaceous plants } \\
(0.7-1.2 \mathrm{~m})\end{array}$ & $\begin{array}{l}\text { Desmodium heterocarpon }{ }^{\wedge}, \text { Waltheria indica }{ }^{\wedge}, \\
\text { Ricinus communis } \wedge \text {, Bidens alba }+, \text { Nephrolepis } \\
\text { biserrata }+, \text { Artemisia scoparia }+, \text { Bougainvillea } \\
\text { glabra }+\end{array}$ & $\begin{array}{l}\text { Waltheria indica }{ }^{\wedge}, \text { Bidens alba }^{\wedge}, \text { Artemisia } \\
\text { scoparia }+\end{array}$ \\
\hline $\begin{array}{l}\text { Small shrubs and } \\
\text { herbaceous plants } \\
(0.2-0.7 \mathrm{~m})\end{array}$ & 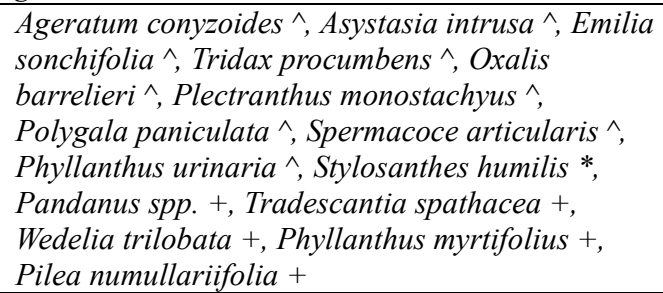 & $\begin{array}{l}\text { Asystasia intrusa } a^{\wedge}, \text { Plectranthus } \\
\text { monostachyus } \wedge\end{array}$ \\
\hline $\begin{array}{l}\text { Tall grasses and } \\
\text { sedges }(>1.2 \mathrm{~m})\end{array}$ & $\begin{array}{l}\text { Melinis repens }{ }^{*}, \text { Setaria italica } \\
\text { polystachion }+ \text { Pennisetum } \\
\text { spontaneum }^{\wedge}\end{array}$ & $\begin{array}{l}\text { Melinis repens }{ }^{\wedge}, \text { Pennisetum polystachion } \\
\wedge, \text { Imperata cylindrica }{ }^{\wedge}\end{array}$ \\
\hline $\begin{array}{l}\text { Medium grasses and } \\
\text { sedges }(0.2-1.2 \mathrm{~m})\end{array}$ & 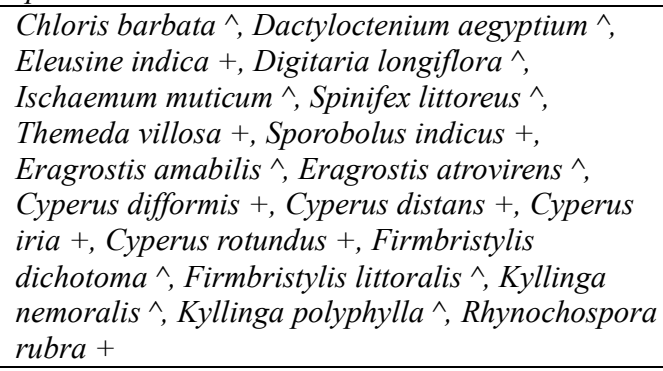 & $\begin{array}{l}\text { Dactyloctenium aegyptium }^{\wedge}, \text { Cyperus } \\
\text { rotundus } \wedge, \text { Firmbristylis dichotoma } \wedge \text {, } \\
\text { Kyllinga brevifolia }^{\wedge}\end{array}$ \\
\hline $\begin{array}{l}\text { Creepers ( Height } \\
\text { stays below } 0.2 \mathrm{~m} \\
\text { when growing along } \\
\text { the ground) }\end{array}$ & $\begin{array}{l}\text { Aneilema nudiflorum }{ }^{\wedge}, \text { Calopogonium mucunoides } \\
\wedge, \text { Ipomoea cairica }+ \text {, Ipomoea obscura }{ }^{\wedge} \text {, Clitoria } \\
\text { ternatea }+, \text { Mikania micrantha } \wedge \text {, Smilax } \\
\text { calophylla } \wedge\end{array}$ & $\begin{array}{l}\text { Calopogonium mucunoides } \wedge \text {, Ipomea } \\
\text { triloba } \wedge\end{array}$ \\
\hline $\begin{array}{l}\text { Groundcovers }(< \\
0.2 \mathrm{~m})\end{array}$ & $\begin{array}{l}\text { Axonopus compressus }+, \text { Desmodium } \text { trifolium }^{\wedge} \\
\text { Mimosa } \text { pudica }^{\wedge}, \text { Indigofera hirsuta }^{*}, \text { Arachis } \\
\text { pintoi }^{*}\end{array}$ & Axonopus compressus,+ Mimosa pudica ${ }^{\wedge}$ \\
\hline
\end{tabular}

On Roof A, of a total of 50 seed species scattered, 6 species were observed to have established themselves: Leucaena leucocephala, Crotalaria pallida, Crotalaria retusa, Stylosanthes humilis, Melinis repens, and Indigofera hirsuta. Sixteen of the 23 transplanted plant species were left after 16 months. Of these, 6 were noted to be thriving and spreading widely, Pennisetum polystachion, Bidens alba, Stachytarpheta indica, Clitoria ternatea, Sporobolus indicus, and Eleusine indica. There was a total of 34 spontaneous species, with only 1, Ricinis communis, failing to establish itself; it lasted only a few months after being introduced.

On Roof B, 1 of the 50 seeded species, Crotalaria pallida, managed to establish itself. All 3 transplanted species were still surviving after 16 months, but none was spreading. There were 19 spontaneous species observed, all managing to become established. 


\section{Flora coverage}

The sites started out as bare substrate when the project began in December 2013. A series of seeding and transplanting was carried out over the first 3 months (Table 1), but plant growth was slow for the first five months. The first record of data, from May 2013 (5 months), shows $30 \%$ cover on Roof A and $80 \%$ on Roof B. Plant growth was faster after that, reaching $95.9 \%$ and 100\% site cover respectively by December 2013 (12 months). After December 2013, though, both sites experienced large changes from external forces, resulting in very different site coverage percentages in the last recorded data in April 2014 (16 months).

For Roof $\mathrm{A}$, trees were trimmed to a $3 \mathrm{~m}$ height from $4-5 \mathrm{~m}$ after the $12^{\text {th }}$ month record for safety considerations, as the $5 \mathrm{~cm}$ soil depth was unlikely to support their height. A large percentage of the semi-perennial Crotalaria died during the $14^{\text {th }}$ month, in February 2014; this is typically the driest and hottest month in Singapore. The collapse of this species facilitated the spread of spontaneous species and a change in plant composition (Figure 1 and Table 4).

In the case of Roof $\mathrm{B}$, the tall shrub Crotalaria pallida which was around $1.8 \mathrm{~m}$ and occupying $86.7 \%$ of the site by the $12^{\text {th }}$ month was trimmed down to $1.0 \mathrm{~m}$ after the $12^{\text {th }}$ month data record, to allow the growth of other species observed to be growing under its canopy. These species were able to better establish themselves. The Crotalaria on Roof B were largely unaffected by the harsher conditions during February 2014, unlike Roof A (Figure 2 and Table 4).

Figure 1. Percentage of each plant structure type with respect to the total site area for Roof A.

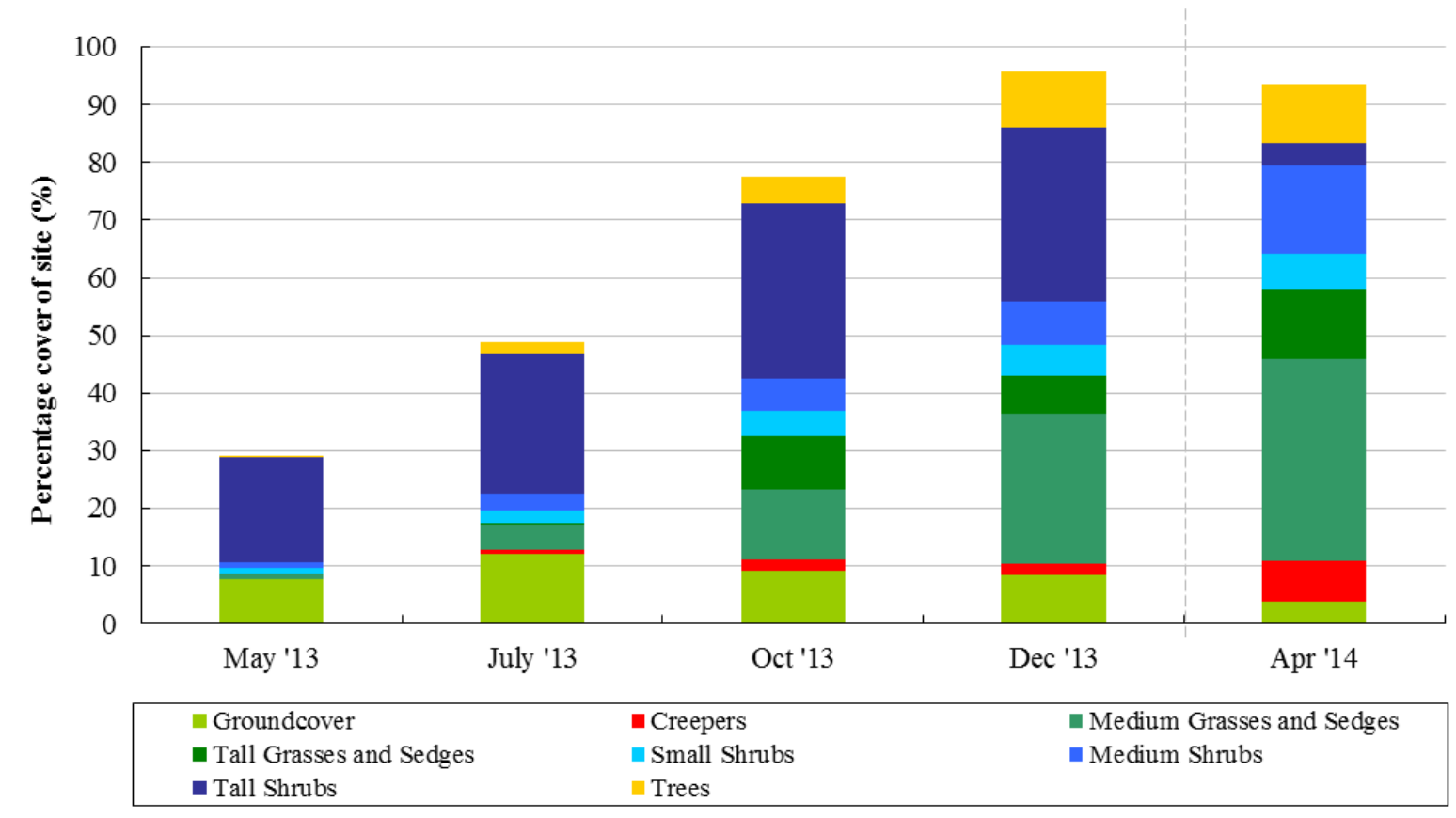


Figure 2. Percentage of each plant structure type with respect to the total site area for Roof B.

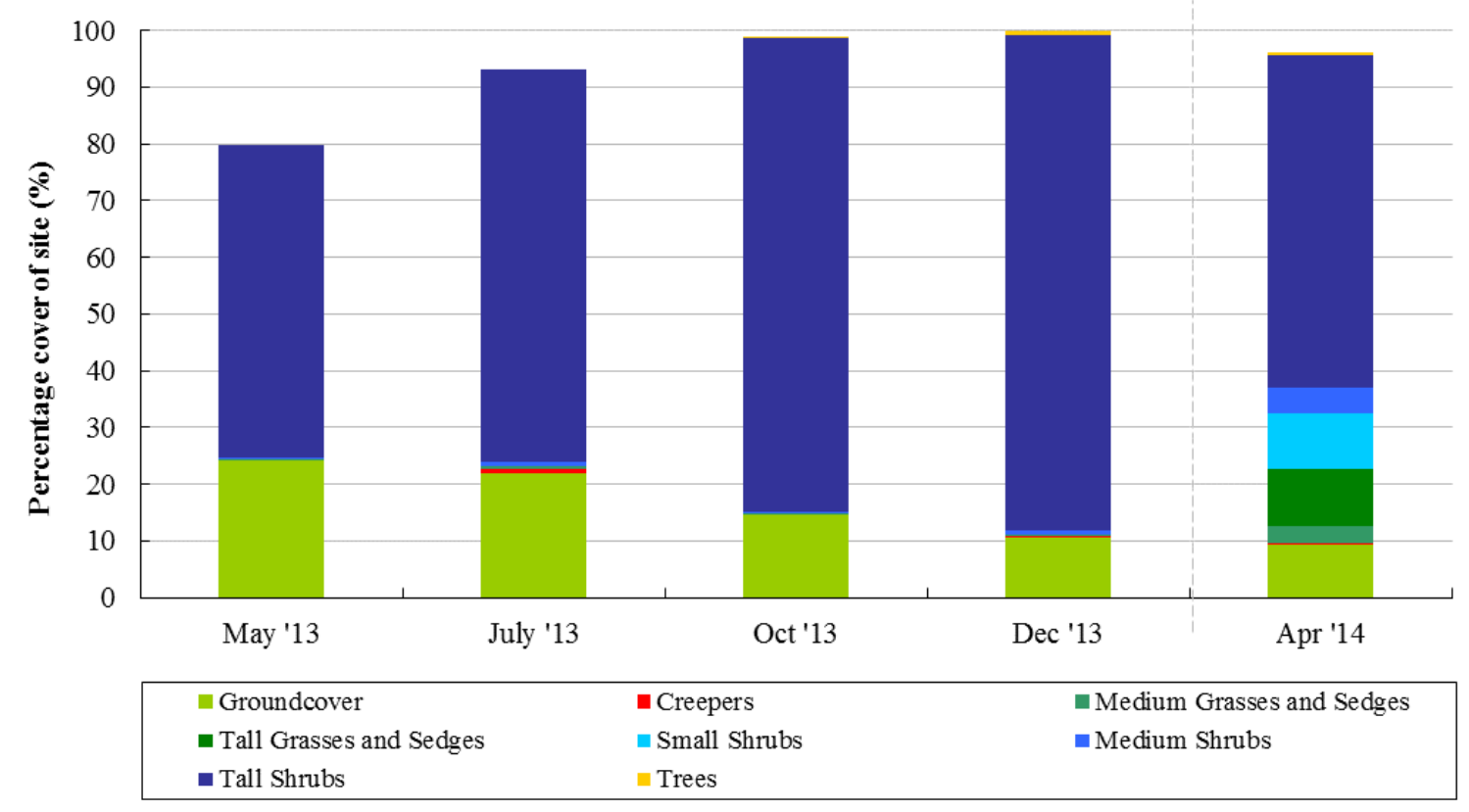

\section{Spatial distribution of flora}

For Roof A, the main vegetation structure was 'tall shrubs and herbs', with $30.2 \%$ site cover in the $12^{\text {th }}$ month, followed by 'medium grasses and sedges' with $26.0 \%$. The 'tall shrubs and herbs' category was mainly represented by Crotalaria spp., which represented $25.3 \%$ of the $30.2 \%$ cover in the $12^{\text {th }}$ month; this was also the most prominent species up to the $12^{\text {th }}$ month. There were 3 tree species, with a total of $9.6 \%$ site cover by the $12^{\text {th }}$ month. This was mostly from multiple Leucaena leucocephala and Sesbania sesban trees and seedlings, along with one Mimosa pigra tree which had $1.4 \%$ site cover.

Spontaneous species had $28.9 \%$ site cover in the $12^{\text {th }}$ month. Most of this came from the growth of spontaneous medium grasses and sedges, representing $18.2 \%$ site cover, followed by the tall shrub Neptunia plena at $4.2 \%$. Following the death of most of the Crotalaria, spontaneous species cover increased to $49.14 \%$, roughly corresponding with the decrease in Crotalaria spp. from $25.3 \%$ to $1.6 \%$ between the $12^{\text {th }}$ and $16^{\text {th }}$ months. A large portion of the former Crotalaria area was taken over by the growth of shorter spontaneous species: a small herb, Asystasia intrusa, increased its site cover from $0.01 \%$ to $5.5 \%$, and spontaneous medium grasses and sedges jumped from $18.2 \%$ to $33.5 \%$. Ipomea obscura, a creeper, spread quickly over the dead Crotalaria branches, increasing its site cover from $0.2 \%$ to $6.6 \%$.

On Roof B, there was little site cover from trees, as no trees were seeded or transplanted, and the only species to grow spontaneously, Acacia auriculiformis, was periodically removed as part of campus policy (Table 1). The main vegetation structure was 'tall shrubs and herbs', with $87.2 \%$ and $86.7 \%$ cover respectively by the $12^{\text {th }}$ month. Crotalaria was again the most prominent species; at 5 months, it already made up $54.9 \%$ of the total $79.8 \%$ site coverage. The remaining site cover was mainly occupied by the transplanted groundcover grass Axonopus compressus; it represented $24.2 \%$ of the cover in the $5^{\text {th }}$ month, but this decreased to $10.7 \%$ in the $12^{\text {th }}$ month, as Crotalaria grew over it (Table 4). 
Table 4. Mapping of flora site cover and spatial distribution of flora (white areas indicate bare substrate)

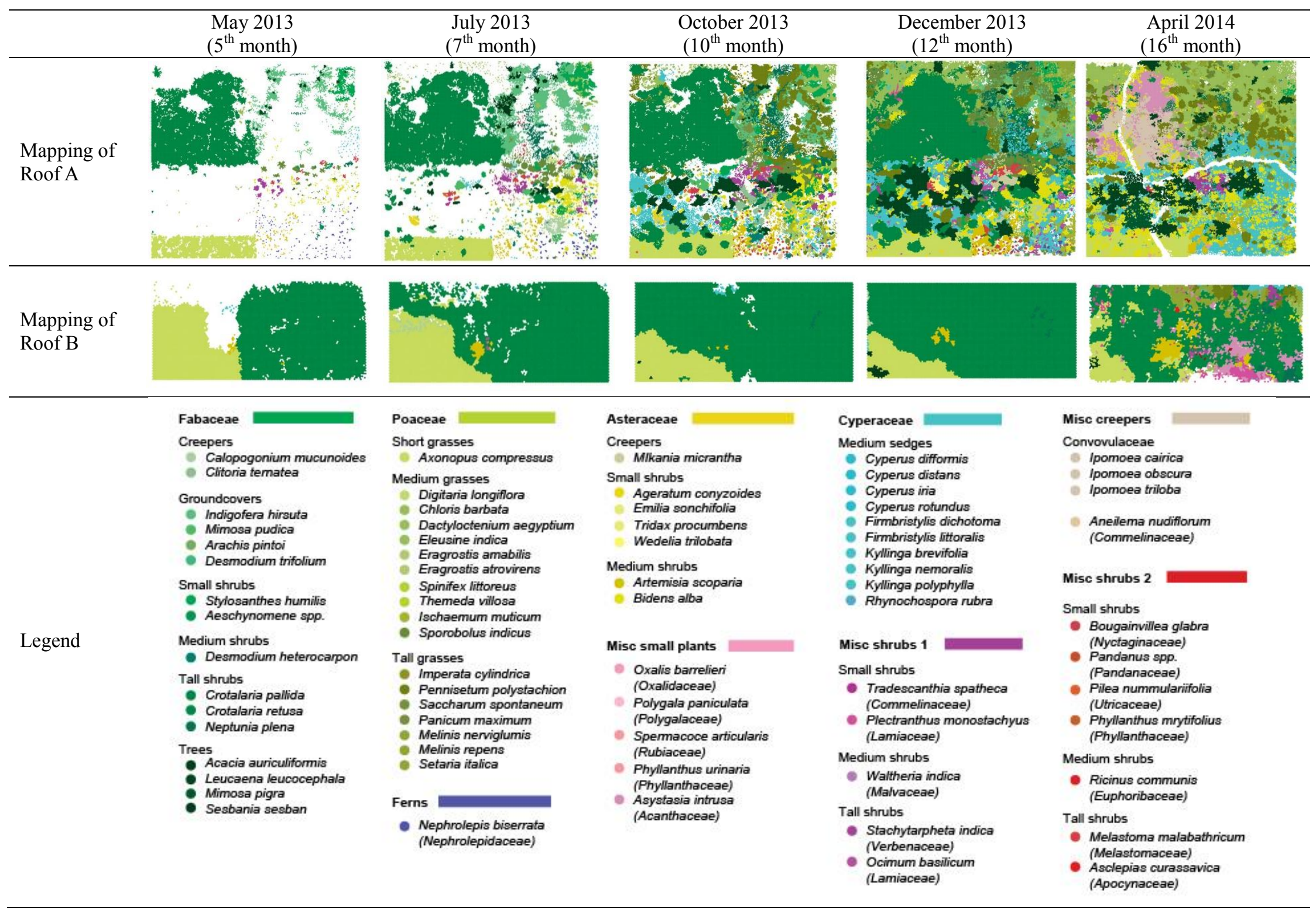


Roof B had little spontaneous site cover in the first 12 months because of the thick and tall Crotalaria covering most of the site. After it was trimmed, spontaneous species had jumped to $26.4 \%$ of the cover by the $16^{\text {th }}$ month. Similar to Roof A, this was partly because of shorter species; the small herb Asystasia intrusa had site coverage of $6.7 \%$, and the small herb Plectranthus monostachyus had 3.2\%. Tall grasses Pennisetum polystachion and Melinis repens, transplanted only on Roof A, established themselves on Roof B, with $2.2 \%$ and $7.6 \%$ coverage respectively. Two other spontaneous species, Stachytarpheta indica and Bidens $a l b a$, were also transplanted species on Roof A.

\section{Fauna diversity}

Few birds were observed on the concrete roofs before the green roofs were installed; Javan mynas and Yellow-vented bulbuls perched on the nearby railings but had little interaction with the roof surface. Over the course of 16 months from December 2012 to June 2014, a total of 69 fauna species, including 6 species of birds, 13 bees, hornets, and wasps, 15 butterflies and moths, 5 flies, 3 spiders, 5 ants, 9 beetles, 8 species of true bugs, 1 dragonfly, 2 grasshopper, 1 katydid, and 1 cricket were observed on Roof A. The most diverse taxa were butterflies and moths, followed by species of bees, hornets, and wasps on Roof A (Table 5). Meanwhile, on Roof B, 21 species of fauna were recorded during the same period, including 3 species of birds, 9 bees, hornets, and wasps, 3 butterflies and moths, 1 fly, 2 ants, 1 beetle, and 2 true bugs. The most diverse grouped taxa were bees, hornets, and wasps, followed by butterflies and moths on Roof B (Table 5).

The most numerous group of fauna on both roofs were bees, hornets and wasps. This group has difficulty surviving on ground level on the university campus because of the frequent fogging to kill mosquitoes; this, coupled with the numerous flowering species on the roofs, attracts many to the roofs. There are only 2 butterfly host plants on the roofs: Crotalaria pallida and Mimosa pigra, the former being seeded and the latter growing spontaneously, but many of the other flowering plants are nectar plants to a variety of butterfly species, thus attracting numerous butterflies to both roofs. Other plant species are noted for directly attracting certain fauna species. The tall seed bearing Pennisetum polystachion and Melinis repens attract Scaly breasted Munias, and Spotted doves often rest under the dense upper branches of the tall Crotalaria. Fauna are also attracted by existing fauna. Spiders, particularly the Burmese lynx spider, prey on the smaller bees; Lacewings lay eggs near aphids or caterpillars, which become food for the larvae; parasitoid wasps, such as the Delta spp. Potter wasp attack caterpillars to lay their eggs.

\section{Roof sizing}

The $662 \mathrm{~m}^{2}$ sized Roof A achieved a greater variety of plant species and fauna species, than the $79 \mathrm{~m}^{2}$ sized Roof B (Table 3 and Table 5), although both were of similar height and regional context. The larger roof had almost three times the number of species of flora and fauna, with 23 species of flora observed on Roof B compared to 64 on Roof A. Only 3 species of birds were spotted and 18 species of arthropods were found on the smaller Roof B. Meanwhile, Roof A boasted 6 bird species and 63 species of arthropods. In other words, the area of the green roof may have affected its capacity to support increased biodiversity. 
Table 5. List of observed fauna species on Roof A and Roof B for 16 months.

\begin{tabular}{l}
\hline Roof A \\
\hline Birds \\
Spotted dove (Spilopelia chinensis), Scaly breasted Munia (Lonchura \\
punctulata), Collared Kingfisher (Todiramphus chloris), Yellow-vented \\
Bulbul (Pycnonotus goiavier), Common myna (Acridotheres tristis). Asian \\
glossy starling (Aplonis panayensis) \\
Bees, Hornets and Wasps \\
Dwarf honeybee (Apis andreniformis), Common Asian honeybee (Apis \\
cerana), Carpenter bee (Xylocopa aestuans), Giant Carpenter bee (Xylocopa \\
latipes), Leafcutter bee (Megachile sp.), Cuckoo bee (Thyreus himalayensis), \\
Blue-banded bee (Amegilla sp.), Leafcutter bee (Chalicodoma disjuncta), \\
Greater banded hornet (Vespa affinis), Horntail wasp (Siricidae), Paper wasp \\
(Polistes sp), Potter wasp (Delta sp.), Potter wasp (Rhynchium \\
haemorrhoidale)
\end{tabular}

\section{Butterflies and Moths}

Pea blue butterfly (Lambides boeticus), Common Red Flash (Rapala iarbus iarbus), Plain tiger (Danaus chrysippus chrysippus), Peacock

pansy (Junonia almana), Striped Albatross (Appias libythea olferna), Mottled emigrant (Catopsilia pyranthe pyranthe), Common grass yellow (Eurema hecabe contubernalis), Day-flying Moth (Lymantriinae), Arctiid moth (Creatonotos transiens), Crambid moth (Crambidae), Gypsy moth (Lymantria spp.), Tussock moth (Lymantriidae), Bagworm moth

(Psychidae), Bagworm moth (Chalioides sumatrensis), Ricanul sp.(Ricanula stigmatica)

\section{Flies (Diptera, Neuroptera)}

Green bottlefly (Calliphoridae), Scavenger fly (Milichiidae), Common housefly (Musca domestica), Hoverfly (Eristalinus spp), Green lacewing (Chrysopidae)

\section{Spiders}

Jumping spider (Salticidae), Burmese lynx spider (Oxyopes birmanicus), Crab spider (Thomisus $s p$.)

\section{Ants}

Ant (Polyrhacis spp), Yellow Crazy Ant (Anoplolepis gracilipes), East Indian harvesting ant (Carebara diversa), Slender ant (Tetraponera sp.), Large Dolly Ant (Dolichoderus sp.)

\section{Beetles}

Ladybird beetle (Cryptogonus orbiculus), Ladybird beetle (Cheilomenes sexmaculata), Netty ladybird beetle (Heteroneda reticulata), Net-winged Beetle (Lycidae), Dwarf shield bug (Coptosoma spp.), Netwing beetle (Lycostomus sp), Flower Chafer (Scarabaeidae), Flower Chafer (Glycyphana sp.), Fungus weevils (Anthribidae)

\section{True bugs (Hemiptera)}

Aphid (Aphidoidea), Shield bug (Alcaeus spp.), Broad headed bug (Alydidae), Stink Bug (Eocanthecona furcellat), Scale insect (Coccoidea), Treehopper (Tricentrus spp.), Shield bug (Brachyplatys sp), Bean Bug (Riptortus linearis)

Misc.

Common scarlet dragonfly (Crocothemis servilia), Giant grasshopper (Valanga nigricornis), Conehead katydid (Conocephalus maculatus), Coneheaded Grasshopper (Atractomorpha psittacina), Cricket

\begin{tabular}{lll} 
No & Roof B & No \\
\hline 6 & Birds & 3
\end{tabular}

Spotted dove (Spilopelia chinensis), Scaly breasted Munia (Lonchura punctulata), Asian glossy starling (Aplonis panayensis)

13 Bees, Hornets and Wasps Dwarf honeybee (Apis andreniformis), Common asian honeybee (Apis cerana), Carpenter bee (Xylocopa aestuans), Giant Carpenter bee (Xylocopa latipes), Leafcutter bee (Chalicodoma disjuncta), Paper wasp (Polistes $s p$ ), Potter wasp (Delta spp.), Potter wasp (Rhynchium haemorrhoidale), Mud dauber wasp (Chalybion spp.)

15 Butterflies and Moths

Pea blue butterfly (Lambides boeticus), Day-flying Moth (Lymantriinae), Bagworm moth (Psychidae)

$5 \quad$ Flies (Diptera, Neuroptera) Green lacewing (Chrysopidae)

$3 \quad$ Spiders

\section{$5 \quad$ Ants}

Yellow Crazy Ant (Anoplolepis gracilipes), Slender ant (Tetraponera sp.)

9 Beetles

Ladybird beetle (Cheilomenes sexmaculata)

8 True bugs (Hemiptera) Aphid (Aphidoidea), Stink Bug (Eocanthecona furcellat)

$5 \quad$ Misc. 


\section{DISCUSSION}

\section{Green roofs are able to support many types of plant structures}

Eight types of vegetation structure, including trees, tall shrubs, medium shrubs, small shrubs, tall grasses and sedges, medium grasses and sedges, creepers, and groundcovers, are capable of surviving, even thriving, with minimal maintenance on a green roof. Similar studies in temperate regions have similar findings, one recording 6 species (Lundholm, 2015) and the other recording all 8 vegetation structures (Dunnett et al., 2008). In both, there is an absence of or few species in the 'tall shrubs and herbs' and 'trees' categories, however, and the trees recorded in our study likely remained seedlings in theirs. In contrast, in our Singapore study, 'tall shrubs and herbs' and 'trees' are the most dominant categories, with a combined $40 \%$ and $88 \%$ total coverage for the $12^{\text {th }}$ month on Roof A and B respectively, and comprising $14 \%$ and $34 \%$ of the species richness of the two roofs.

This should change the understanding of green roof planting schemes in the tropics. Extensive green roofs are clearly capable of supporting multiple vegetation structures and are not limited to the one or two vegetation structures typically used. In addition to the aesthetic variety allowed by using more vegetation structures, augmenting the scope of a green roof would enhance an ecosystem's functions, no matter if it were a constructed or wild landscape (Lundholm, 2015).

\section{Green roof plant establishment and maintenance}

This study used methods of transplanting and seeding plants to help establish vegetation on the two green roofs with mixed results. Few of the seeded plants grew, but those few were very successful; for example, Crotalaria spp. occupied $25 \%$ and $87 \%$ in the $12^{\text {th }}$ month on Roof A and B respectively. Similarly, most transplanted species either did not survive or did not spread much, but a few spread quickly; for example, on Roof A, Pennisetum polystachion and Bidens alba respectively represented $10 \%$ and $14 \%$ of the cover by the $16^{\text {th }}$ month. Further studies are needed to determine if this is a result of unfavorable microclimatic conditions on the roof for those that failed, or if they were unable to compete with the more successful species and those species that grew spontaneously.

Spontaneous species accounted for a large proportion of the two roofs' coverage, as well as the species richness (Table 2 and Table 3). These results support the position that permitting unplanned, spontaneous species to propagate can add biodiversity to green roofs. Spontaneous species growth and spread was noted to be fast; within 12 months, certain species had established conditions similar to those observed on ground-level sites left unmaintained (Hwang, 2011). Therefore, simply halting regular intensive maintenance on existing green roofs and leaving sites to establish themselves may be a method of creating ecologically sustainable roofs.

Relying on spontaneous vegetation has some drawbacks, however. Spontaneous plant composition was noted to vary between roofs; in this study, the two roofs had the same AMSL and were in close proximity, but still had different compositions. As colonizing species are mostly likely to be ruderal species, there is also a risk of the green roof developing into low diversity systems, with several aggressive species dominating the site (Dunnett et al., 2008). The rapid growth of Asystasia intrusa and Ipomea obscura in the $16^{\text {th }}$ month record for Roof A suggests that without maintenance, spontaneous species can quickly alter the plant composition and design of green roofs. Human intervention to control those aggressive species is still necessary to manage spontaneous plant growth.

Besides being necessary to prevent aggressive species from dominating the site, maintenance could be a safety requirement, for example, trimming plants whose height makes them susceptible to collapse or removing species that would damage the building structure. It may also be necessary to promote the growth of favored species, by trimming 
neighboring plants to allow more room for growth, or to maintain certain species mixes for their ecosystem services. The changes in vegetation growth recorded in the $16^{\text {th }}$ month for Roof B after trimming the tall $1.8 \mathrm{~m}$ Crotalaria $s p$. to $1.0 \mathrm{~m}$ demonstrates how maintenance can promote biodiversity. Further studies should consider the minimum area required for a particular species to be self-sustaining.

\section{Influence of green roof flora on fauna}

The two green roofs attracted a variety of fauna, without being specially designed for this purpose, largely supporting the 'field of dreams' approach to green roofs, whereby 'if you build it, they will come' (Coffman and Waite 2011). The attracted fauna represented different orders, indicating the capacity of a minimally maintained extensive green roof to support a variety of fauna. As mentioned earlier, the interrelationship between fauna species, such as the Burmese lynx spider preying on smaller bees, suggests green roofs can regulate and sustain themselves to a certain extent.

No uncommon or endangered species were noted on either green roof in this study, in contrast to Brenniesen (2006) who recorded several endangered species in a similar study. This is likely due to the absence of endangered species in the immediate vicinity, coupled with the lack of suitable conditions, such as large tree canopies, to attract the endangered owls known to frequent the area. Coffman and Waite (2011) note that certain green roofs used in their study had ideal conditions to provide particular ecosystem services, such as stopover habitats for migratory birds, while others had less variety of fauna because of factors like roof height and nearby vegetation. We made similar observations on the two roofs in this study. Only butterfly species that had their host plant present on site were commonly observed; the majority of other butterfly species observed were visitors from surrounding vegetation. Likewise, Munias came for seeds from Pennisetum spp. and Melinis spp., which were common after the $10^{\text {th }}$ month, but Kingfishers were present only in the early months, before vegetation grew too dense. This suggests utilizing green roofs to provide ecosystem services for endangered species would be better served by a green roof design targeted at those observed in the vicinity.

\section{CONCLUSION}

Singapore is a highly urbanized city state where ecological development seems challenging. The land must intensify its usage for both humans and nature within a limited space and resources. Yet as this paper shows, creating biodiverse green roofs could be a feasible solution.

Our observations of the plot succession on two roofs in Singapore may contribute to the creation of a framework for planning and designing biodiverse green roofs - setting site context, system, and plant selection. In the end, this framework may become a springboard to boosting biodiversity in the city. This prospect needs to be further studied by analyzing regional faunal sources, fragmentation and connection variables at the planning level, culminating in the designation of large patches as biodiversity hubs linked by smaller patches.

\section{ACKNOWLEDGMENTS}

This work was made possible by funding from NUS-MOE (Ministry of Education) Tier1 Research Fund under Grant Number R-295-000-090-112. The authors also wish to acknowledge NUS The Office of Facilities Management Team for cooperative maintenance support and NUS University Campus Infrastructure team for land use agreement. 


\section{LITERATURE CITED}

Alberti, M.. (2005). The effects of urban patterns on ecosystem function. International regional science review, 28(2), 168-192. doi: 10.1177/0160017605275160

Baumann, N., \& Kasten, F. (2010). Green Roofs - Urban Habitats for Ground-Nesting Birds and Plants. In N. Müller, P. Werner \& J. G. Kelcey (Eds.), Urban Biodiversity and Design. Oxford, UK: Wiley-Blackwell.

Braaker, S., Ghazoul, J., Obrist, M. K., \& Moretti, M. (2014). Habitat connectivity shapes urban arthropod communities: the key role of green roofs. Ecology, 95, 1010-1021. doi: http://dx.doi.org/10.1890/13-0705.1

Brenneisen, S. (2004). From Biodiversity Strategies to Agricultural Productivity. Paper presented at the Greening Rooftops for Sustainable Communities, Portland, Oregon.

Brenneisen, S. (2005, May 2005). Green roofs: recapturing urban space for wildlife - a challenge for urban planning and environmental education. Paper presented at the Third Annual International Green Roofs Conference: Green Rooftops for Sustainable Communities, Washington DC.

Brenneisen, S. (2006). Space for Urban Wildlife: Designing Green Roofs as Habitats in Switzerland. Urban Habitats, 4(1), 27-36.

Brook, B. W., Sodhi, N. S., \& Ng, P.K L. (2003). Catastrophic extinctions follow deforestation in Singapore. Nature, 424, 420 - 423.

Centre for Urban Greenery \& Ecology (Singapore), CUGE, \& National Parks Board (Singapore), NParks. (2010a). Guidelines on Design for Safety for Rooftop Greenery. Singapore: Centre for Urban Greenery and Ecology.

Centre for Urban Greenery \& Ecology (Singapore), CUGE, \& National Parks Board (Singapore), NParks. (2010b). Guidelines on Design Loads for Rooftop Greenery. Singapore: Centre for Urban Greenery and Ecology.

Centre for Urban Greenery \& Ecology (Singapore), CUGE, \& National Parks Board (Singapore), NParks. (2010c). Guidelines on Filter, Drainage and Root Penetration Barrier Layers For Rooftop Greenery. Singapore: Centre for Urban Greenery and Ecology.

Centre for Urban Greenery \& Ecology (Singapore), CUGE, \& National Parks Board (Singapore), NParks. (2010d). Guidelines on Substrate Layer for Rooftop Greenery. Singapore: Centre for Urban Greenery and Ecology.

Centre for Urban Greenery \& Ecology (Singapore), CUGE, \& National Parks Board (Singapore), NParks. (2012a). Guidelines on General Maintenance for Rooftop Greenery. Singapore: Centre for Urban Greenery and Ecology.

Centre for Urban Greenery \& Ecology (Singapore), CUGE, \& National Parks Board (Singapore), NParks. (2012b). Guidelines on Irrigation For Rooftop Greenery. Singapore: Centre for Urban Greenery and Ecology.

Centre for Urban Greenery \& Ecology (Singapore), CUGE, \& National Parks Board (Singapore), NParks. (2012c). Guidelines on Waterproofing For Rooftop Greenery. Singapore: Centre for Urban Greenery and Ecology.

Centre for Urban Greenery \& Ecology (Singapore), CUGE, \& National Parks Board (Singapore), NParks. (2013a). Guidelines on Design and Construction of Pitched Green Roof. Singapore: Centre for Urban Greenery and Ecology.

Centre for Urban Greenery \& Ecology (Singapore), CUGE, \& National Parks Board (Singapore), NParks. (2013b). Guidelines on Planting of Trees, Palms and Tall Shrubs on Rooftop Singapore: Centre.

Centre for Urban Greenery \& Ecology (Singapore), CUGE, \& National Parks Board (Singapore), NParks. (2014a). Guidelines on Design for Safety of Skyrise Greenery. Singapore: Centre for Urban Greenery and Ecology.

Centre for Urban Greenery \& Ecology (Singapore), CUGE, \& National Parks Board (Singapore), NParks. (2014b). Guidelines on Design Loads for Skyrise Greenery. Singapore: Centre for Urban Greenery and Ecology.

Chong, K. Y., Teo, S., Kurukulasuriya, B., Chung, Y.F., Rajathurai, S.j, \& Tan, T. W. H. (2014). Not 
all green is as good: Different effects of the natural and cultivated components of urban vegetation on bird and butterfly diversity. Biological Conservation, 171, 299-309. doi: 10.1016/j.biocon.2014.01.037

Coffman, R. R., \& Waite, T. (2011). Vegetated Roofs as Reconciled Habitats: Rapid Assays Beyond Mere Species Counts. http://www.urbanhabitats.org/v06n01/vegetatedroofs full.html

Collins, J. P., Kinzig, A., Grimm, N. B., Fagan, W. R., Hope, D., Wu, J., \& Borer, E. T. (2000). A new urban ecology. American Scientist, 88(5), 416-425.

Corlett, Richard T. (1992). The Ecological Transformation of Singapore, 1819-1990. Journal of Biogeography, 19(4), 411-420.

Davison, G. W. H., Ng, P. K. L., Ho, H. C., \& Nature, Society. (2008). The Singapore red data book: threatened plants \& animals of Singapore (Vol. 2nd). Singapore: Nature Society.

Dunnett, N., Nagase, A., \& Hallam, A.. (2008). The dynamics of planted and colonising species on a green roof over six growing seasons 2001-2006: influence of substrate depth. Urban Ecosystems, 11(4), 373-384. doi: 10.1007/s11252-007-0042-7

Forman, R. T. T. (1995). Land transformation and fragmentation Land Moisaics: The ecology of landscapes and regions (pp. 406-432). Cambridge, United Kingdom: Cambridge University Press.

Gedge, D., \& Kadas, G.. (2005). Green roofs and biodiversity. Biologist, 52(3), 161-169.

Hwang, Y. H. (2010). Observation of Urban Spontaneous Vegetation as Landscape Material. Journal of Landscape Architecture in Asia, 5(1), 61-71.

Hwang, Y.H. (2011). Emergent vegetation on planned greenery in Singapore. Paper presented at the IFLA Asia-Pacific Regional Congress Thailand, Bangkok.

Hwang, Y. H. (2015). Spontaneous Vegetation: Transforming Manicured Lawns into Selectively Maintained Biodiverse Gardens SUSTAINABLE LANDSCAPE (pp. 101-108). Singapore: Centre for Urban Greenery \& Ecology, National Parks Board.

Inter-Ministerial Committee on Sustainable Development, IMCSD. (2009). Sustainable Development Blueprint. Singapore: Ministry of the Environment and Water Resources

Ministry of National Development Retrieved from http://app.mewr.gov.sg/data/ImgCont/1292/sustainbleblueprint forweb.pdf.

Kadas, G. (2010). Green roofs and biodiversity: can green roofs provide habitat for invertebrates in an urban environment? Saarbrücken: LAP LAMBERT Academic.

Köhler, M. (2006). Long-Term Vegetation Research on Two Extensive Green Roofs in Berlin. Urban Habitats, 4(1), 3-26.

Ksiazek, K, Fant, J. \& Skogen, K.. (2012). An assessment of pollen limitation on Chicago green roofs. Landscape and Urban Planning, 107(4), 401-408. doi: 10.1016/j.landurbplan.2012.07.008

Laurance, W. F. (1999). Reflections on the tropical deforestation crisis. Biological Conservation, 91 , 109-117.

Lundholm, J. T. . (2015). Green roof plant species diversity improves ecosystem multifunctionality. Journal of Applied Ecology. doi: 10.1111/1365-2664.12425

Madre, F., Vergnes, A., Machon, N., \& Clergeau, P.. (2013). A comparison of 3 types of green roof as habitats for arthropods. Ecological Engineering, 57, 109-117. doi: 10.1016/j.ecoleng.2013.04.029

McDonnell, M. J. , \& Pickett, S. T. A. (1993). Introduction: Scope and Need for an Ecology of Subtle Human Effects and Populated Areas. In M. J. McDonnell \& S. T. A. Pickett (Eds.), Humans as Components of Ecosystems: The Ecology of Subtle Human Effects and Populated Areas (pp. 1-5). New York: Springer New York.

McKinney, M. L. (2002). Urbanization, biodiversity, and conservation. Bioscience, 52(10), 883-890.

Murdoch, W. W., Evans, F. C., \& Peterson, C. H. (1972). Diversity and Pattern in Plants and Insects. Ecology, 53(5), 819-829.

National Environment Agency, NEA. (2013, 10 June 2014). Local Climatology. Retrieved 26 January 2015, 2015, from http://www.nea.gov.sg/weather-climate/climate-information

National Parks Board, NParks. (2009). Skyrise Greenery Incentive Scheme Calculation Guide. Singapore: National Parks Board Retrieved from http://www.skyrisegreenery.com/images/uploads/misc/Calculation_guide.pdf.

National Parks Board, NParks. (2013). Skyrise Greenery in Singapore. Retrieved 27 October 2014, 
2014, from

http://www.nparks.gov.sg/cms/index.php?option=com_news\&task=view\&id=341\&Itemid=24 7

Ng, K. L. Peter, Corlett, R., \& Tan, T. W. H. (2011). Singapore biodiversity : an encyclopedia of the natural environment and sustainable development. Singapore: Editions Didier Millet in association with Raffles Museum of Biodiversity Research.

Oberndorfer, E., Lundholm, J., Bass, B., Coffman, R. R, Doshi, H., Dunnett, N., Gaffin, S., Köhler, Liu, K., Rowe, (2007). Green roofs as urban ecosystems: Ecological structures, functions, and services. Bioscience, 57, 823-833.

Pearce, H., \& Walters, Charlotte L. (2012). Do Green Roofs Provide Habitat for Bats in Urban Areas? Acta Chiropterologica, 14(2), 469-478. doi: http://dx.doi.org/10.3161/150811012X661774

Pickett, S. T. A., Cadenasso, M. L., \& McGrath, B. (2013). Ecology of the City as a Bridge to Urban Design Resilience in Ecology and Urban Design: Linking Theory and Practice for Sustainable Cities (Vol. 3, pp. 7-28): Springer Netherlands.

Qin, X., Wu, X., Chiew, Y., \& Li, Y.. (2012). A Green Roof Test Bed for Stormwater Management and Reduction of Urban Heat Island Effect in Singapore. British Journal of Environment \& Climate Chang, 2(4), 410-420.

Schrader, S., \& Böning, M.. (2006). Soil formation on green roofs and its contribution to urban biodiversity with emphasis on Collembolans. Pedobiologia, 50(4), 347-356. doi: 10.1016/j.pedobi.2006.06.003

Snodgrass, E.C., \& McIntyre, L. (2010). Green Roof Basics The Green Roof Manual: A Professional Guide to Design, Installation, and Maintenance (pp. 21-48). Portland, Oregon: Timber Press, Inc.

Soule, M.E., Bolger, D. T., Alberts, A. C., Wright, J., Sorice, M., \& Hill, S.. (1988). Reconstructed Dynamics of Rapid Extinctions of Chaparral-Requiring Birds in Urban Habitat Islands. Conservation Biology, 2(1), 75-92.

Spirn, A. W. (1984). Designing Wildlife Habitats The Granite Garden (pp. 215-226). United States of America: Basic Books.

Tan, Tiang Wah Hugh (2010). The Natural Heritage of Singapore (3rd ed.). Singapore ; New York: Prentice Hall.

United Nations. (2014). World Urbanization Prospects: The 2014 Revision. Country Profile. Retrieved 13 February 2015, from United Nations, Department of Economic and Social Affairs, Population Division http://esa.un.org/unpd/wup/Country-Profiles/Default.aspx

Wong, N. H., Tan, P. Y., \& Chen, Y.. (2007). Study of thermal performance of extensive rooftop greenery systems in the tropical climate. Building and Environment, 42(1), 25-54. doi: 10.1016/j.buildenv.2005.07.030

Wong, N.H., Tan, S. F., Wong, R., Ong, C., \& Sia, A.. (2003). Life cycle cost analysis of rooftop gardens in Singapore. Building and Environment, 38, 499-509.

Yee, A. T. K., Corlett, R. T., Liew, S. C., \& Tan, H. T. W. (2011). The vegetation of Singapore - an updated map. Gardens' Bulletin Singapore, 63(1\&2), 205-212. 